\title{
Chemical and Isotopic Evaluation of Sulfur Sources and Cycling in the Pecos River, New Mexico, USA
}

\author{
Fasong Yuan \\ Cleveland State University, f.yuan06@csuohio.edu \\ Bernhard Mayer \\ University of Calgary
}

Follow this and additional works at: https://engagedscholarship.csuohio.edu/scibges_facpub

Part of the Biogeochemistry Commons, and the Biology Commons

How does access to this work benefit you? Let us know!

\section{Publisher's Statement}

NOTICE: this is the author's version of a work that was accepted for publication in Chemical

Geology. Changes resulting from the publishing process, such as peer review, editing, corrections, structural formatting, and other quality control mechanisms may not be reflected in this document. Changes may have been made to this work since it was submitted for publication. A definitive version was subsequently published in Chemical Geology, 291, January 6, 2012 DOI:10.1016/j.chemgeo.2011.11.014

\section{Recommended Citation}

Yuan F, Mayer B. 2012. Chemical and isotopic evaluation of sulfur sources and cycling in the Pecos River, New Mexico, USA. Chem Geol. 291:13-22.

This Article is brought to you for free and open access by the Biological, Geological, and Environmental Sciences Department at EngagedScholarship@CSU. It has been accepted for inclusion in Biological, Geological, and Environmental Faculty Publications by an authorized administrator of EngagedScholarship@CSU. For more information, please contact library.es@csuohio.edu. 


\title{
Chemical and isotopic evaluation of sulfur sources and cycling in the Pecos River, New Mexico, USA
}

\author{
Fasong Yuan ${ }^{\mathrm{a}, *}$, Bernhard Mayer ${ }^{\mathrm{b}}$ \\ ${ }^{a}$ Department of Biological, Geological, and Environmental Sciences, Cleveland State University, 2121 Euclid Ave, Cleveland, OH 44115, USA \\ ${ }^{b}$ Department of Geoscience, University of Calgary, 2500 University Drive N.W., Calgary, Alberta, Canada T2N 1N4
}

\section{Introduction}

Sulfur is an essential element for life because nearly all organisms in terrestrial ecosystems require it as a macronutrient for the formation of amino acids, enzymes, vitamins, and other compounds (Solomon et al., 2005). Since sulfur is biologically active in many ecosystems, concentrations and isotopic compositions of dissolved sulfate in surface waters usually fluctuate in response to environmental changes (Van Stempvoort and Krouse, 1994). Over the last several decades, many studies have documented the influence of changes in atmospheric acid deposition on sulfur dynamics in temperate forest ecosystems of North America and Europe (e.g., Richter et al., 1983; Mayer et al., 1995b; Mitchell et al., 1998; Shanley et al., 2005). However, studies that evaluate the influence of land use change and climate variability on sulfur dynamics in the environment are scarce (e.g., Rock and Mayer, 2009). Such studies are extremely rare for the dryland ecosystems in the American Southwest, which are often impacted by high levels of total dissolved solids (TDS) from naturally-occurring ancient evaporites.

It is highly desirable to know how land use activities have influenced the sulfur dynamics in dryland ecosystems. Unlike temperate ecosystems, dryland ecosystems usually receive low inputs of mean annual precipitation and have high potential evapotranspiration. Dryland rivers are characterized by long periods of low flow, high hydrologic diversity, and extremely large flow variability (Davies et al., 1996). Agricultural practices introduce additional water and dissolved salts from surface water and groundwater sources onto cultivated farmlands. Dissolved salts tend to build up on irrigated farmlands during dry climatic conditions and may be flushed out during floods or storms (Hernandez, 1978; Yuan et al., 2007). The great potential of land salinization and degradation in dryland environments 
has concerned farmers and soil scientists for many decades (Scofield, 1940; El-Ashry et al., 1985).

The Pecos River is one of the saltiest river systems in the American Southwest. Over the last several decades, much of the research on the Pecos River has been driven by the need to improve the understanding of the mechanisms that control its water salinity and chemistry. Howard and White (1938) described marked increases in dissolved salt loading of the river near the Artesia and Malaga areas. Gibbs (1970) examined the relationship between the TDS and the $\mathrm{Na} /(\mathrm{Na}+\mathrm{Ca})$ ratio and underscored the importance of evaporation-crystallization in controlling the water salinity and stream chemistry of the Pecos River. Yuan and Miyamoto (2005) developed a hydrochemical model to discriminate dominant processes controlling the water chemistry of the Pecos River. Yuan et al. (2007) reported that change in water chemistry of the Pecos River is driven by large-scale climatic variability such as the Pacific Decadal Oscillation (PDO). More recently, Yuan and Miyamoto (2008) reported $\delta{ }^{18} \mathrm{O}$ and $\delta \mathrm{D}$ values of surface waters in the Pecos River basin. These studies not only demonstrated that the water chemistry of the Pecos River is controlled by climatic, hydrologic, and lithologic variables but also suggested that land use activities may play an important role in regulating water chemistry of the Pecos River. Nevertheless, there is a lack of studies that evaluate the role of watershed biogeochemical processes on stream chemistry. Particularly, little is known about the influence of agricultural practices on sulfur cycling and transport in the dryland environment of the American Southwest.

Stable isotope compositions of dissolved sulfate $\left(\delta^{18} \mathrm{O}_{\mathrm{SO} 4}\right.$ and $\delta^{34} S_{\text {SO4 }}$ values) have been widely used to delineate sulfate sources and assess sulfur cycling in watersheds. Sulfates from different sources may be characterized by distinct isotopic signatures (e.g., Krouse and Grinenko, 1991). Dissolved sulfates in stream waters may retain their sulfur isotopic signatures of the source rocks due to minimal isotope fractionation during sulfur transformations under aerobic conditions (e.g., soil adsorption/desorption, mineral precipitation/ dissolution, plant assimilation, and mineralization of organic sulfur). Substantial sulfur isotope fractionation occurs during bacterial (dissimilatory) sulfate reduction (Nakai and Jensen, 1964; Ingvorsen et al., 1981). In contrast, little sulfur isotope fractionation occurs during the oxidation of sulfide minerals and organic sulfur to form sulfate (e.g., Mayer et al., 1995a; Schiff et al., 2005; Shanley et al., 2005; Tuttle et al., 2009). On the other hand, $\delta^{18} \mathrm{O}_{\mathrm{SO}}$ values can change considerably because some of the oxygen in dissolved sulfate can be incorporated from ambient water $\left(\mathrm{H}_{2} \mathrm{O}\right)$ and dissolved oxygen molecules $\left(\mathrm{O}_{2}\right)$ during biologically or chemically mediated sulfur oxidation. The oxygen isotope ratio of the newly formed sulfate depends on a number of factors, including the reaction pathways, the relative contributions to $\mathrm{SO}_{4}-\mathrm{O}$ from $\mathrm{H}_{2} \mathrm{O}$ and $\mathrm{O}_{2}$, the $\delta^{18} \mathrm{O}$ values of ambient $\mathrm{H}_{2} \mathrm{O}$ and $\mathrm{O}_{2}$, and the ambient environmental conditions ( $\mathrm{pH}$, temperature, and specific oxidizing agents) (Van Stempvoort and Krouse, 1994; Balci et al., 2007).

The purpose of our study was to determine the chemical and isotopic compositions of water and dissolved sulfate of surface and groundwater samples from the Pecos River basin and examine the relationships among those chemical and isotopic parameters to gain novel insights about causes controlling salinity in this dryland ecosystem. The main objectives of this work were 1 ) to discriminate major sources of dissolved sulfate in this dryland river, 2) to examine the major processes controlling sulfate cycling and transport in the watershed, and 3) to evaluate the influence of land use activities on sulfur cycling and transport in the Pecos River basin. It was anticipated that the obtained information would be valuable for dryland ecosystem management in the Pecos River and that the study would add to the currently sparse knowledge about sources and cycling of sulfur in the arid and semiarid regions of North America (e.g., Rock and Mayer, 2009; Tuttle et al., 2009).

\section{Study area}

The Pecos River originates in the southern part of the Sangre de Cristo Mountains, flows south across eastern New Mexico, and enters Red Bluff Reservoir in western Texas (Fig. 1). It drains an area of 50, $000 \mathrm{~km}^{2}$ in eastern New Mexico (USGS, 2010), which can be divided into an upper basin of $6,000 \mathrm{~km}^{2}$ above Santa Rosa Lake and a lower basin of $44,000 \mathrm{~km}^{2}$ above Red Bluff Reservoir. The hydrology of the Pecos River is rather heterogeneous and strongly influenced by changes in topography, climate, and the lithologic properties of the underling rocks (Harrington, 1957; Summers, 1972; Yuan and Miyamoto, 2004; Yuan and Miyamoto, 2005; Yuan et al., 2007). In the upper basin, the Pecos River receives snowmelt from the headwater region located in the high mountains of the southern Rockies (elevation above $2000 \mathrm{~m}$ ), with a relatively low mineral content (TDS $<250 \mathrm{mg} / \mathrm{L}$ ) (SWQB, 2003). These mountains consist of conglomerates, sandstones, and limestones of Paleozoic age, and granites, gneisses, and schists of Precambrian age (Sidwell, 1941; Harrington, 1957). In the lower basin, the Pecos River receives water from multiple sources, including natural spring water, agricultural drains, runoff from monsoonal rainfall, and stream flow upstream with a relatively high mineral content (TDS $>1000 \mathrm{mg} / \mathrm{L}$ ) (Yuan and Miyamoto, 2005; Yuan et al., 2007).

The abrupt increase in the mineral content of the Pecos River near Santa Rosa is largely due to the dissolution of ancient evaporites in the lower basin, as indicated by many "bottomless" lakes scattered in the area (Harrington, 1957; Yuan and Miyamoto, 2005). The geologic framework of this basin has been documented extensively (e.g., Summers, 1972; Risser, 1987; Havenor, 2003). Permian evaporites (halite, anhydrite, and gypsum) occur in several geological units in the area, such as the San Andres, Bernal, Seven Rivers, Yates, Tansill, Castile, Salado, and Rustler Formations. The stratigraphic sequence varies throughout the basin. The Bernal Formation containing seams of anhydrite and limestone prevails in the northern part of the basin (Risser, 1987), with a northwestern limit near the Bernal and Villanueva area (Lucas, 1991). The Artesia group (Seven Rivers, Yates, and Tansill Formations) occurs in the middle part of the basin (mainly in the Roswell Basin). The upper Permian group (Castile, Salado, and Rustler Formations) mainly occurs in the southern part of the basin. The lower Permian unit (San Andres Formation) containing gray dense limestone and anhydrite occurs in many parts of the basin.

The Pecos River traverses several different hydroclimatological zones with distinct vegetation communities (e.g., alpine tundra, evergreen needle-leaf forest, shrubland, and grassland). Annual precipitation is on average $300 \mathrm{~mm}$ although it can exceed $700 \mathrm{~mm}$ in the mountainous headwater areas (Thomas, 1963). The upper Pecos River is affected by the Pecos mine drainage (Fig. 1) but has otherwise experienced little land use change. There are three irrigation districts in the lower basin, namely Fort Sumner Irrigation District (FSID), Pecos Valley Artesian Conservancy District (PVACD), and Carlsbad Irrigation District (CID). FSID and CID divert water from the river while PVACD pumps groundwater from the Roswell Artesian basin.

\section{Materials and methods}

Surface and groundwater samples were collected from eighteen locations in the Pecos River basin for chemical and isotopic analyses. The sampling was carried out during the snowmelt season in March 2010. Consideration of sampling site selection included site accessibility, spatial coverage, the degree of increases in dissolved sulfate flux along the Pecos River, and the significance of aquifers for agricultural practices in this region. Surface water samples were collected by hand-dipping along the river shore at a water depth of $10-15 \mathrm{~cm}$. Clean sample bottles were filled slowly to minimize post-sampling alteration in isotopic compositions. Groundwater samples were taken 


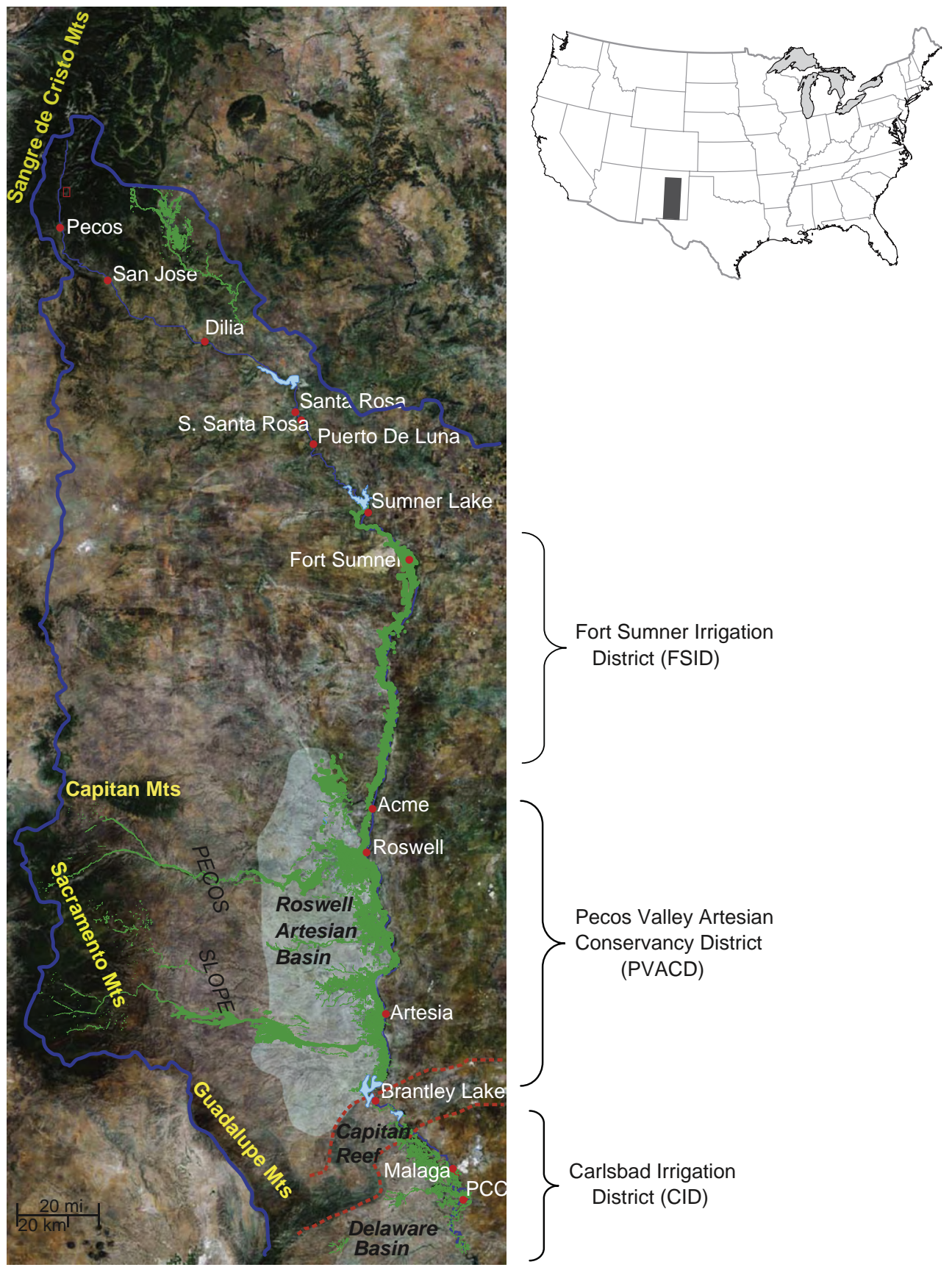

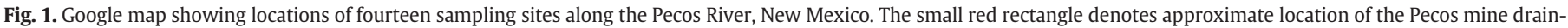

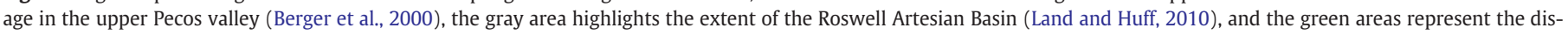
tribution of irrigated farmlands in this basin (Longworth and Carron, 2003). The solid blue line refers to the drainage boundary of the Pecos River.

from farm wells near the Agricultural Science Center of New Mexico State University in Artesia. Two groundwater samples were taken from the shallow alluvial aquifer and the other two samples from the deep Artesian aquifer.

Water samples were shipped to Cleveland State University for subsampling, treatment, and chemical and isotopic analyses. About $30 \mathrm{~mL}$ of water was subsampled and filtered from each water sample for chemical analyses at Cleveland State University, using an ion chromatography unit (ICS-1500). The relative errors for $\mathrm{Cl}^{-}$and $\mathrm{SO}_{4}^{2-}$ were $1.0 \%$ and $1.5 \%$, respectively. About $1 \mathrm{~mL}$ of water was subsampled and filtered for analysis of $\delta^{18} \mathrm{O}$ and $\delta \mathrm{D}$ of water at Dr. Karr's laboratory of Duke University, using a Thermo Finnigan TC/EA with GC-PAL autosampler attached to a Thermo Finnigan Delta Plus XL continuous flow mass spectrometer via a Conflo III interface. The isotopic values are reported using the standard $\delta$ notion relative to Vienna-Standard Mean Ocean Water (V-SMOW). The analytical precisions for $\delta^{18} \mathrm{O}$ and $\delta \mathrm{D}$ of water were $\pm 0.1 \%$ and $\pm 1.5 \%$, respectively.

Water samples were filtered and acidified with $3 \mathrm{M} \mathrm{HCl}$ to remove dissolved carbonates and bicarbonates in water. $\mathrm{BaSO}_{4}$ was precipitated using $0.5 \mathrm{M} \mathrm{BaCl}_{2}$, collected by filtration, rinsed with deionized water, and oven-dried at $60{ }^{\circ} \mathrm{C}$. Analyses of $\delta^{18} \mathrm{O}$ and $\delta^{34} \mathrm{~S}$ values of sulfate were conducted at the University of Calgary via continuous flow isotope ratio mass spectrometry. $\delta^{18} \mathrm{O}_{\mathrm{SO} 4}$ and $\delta^{34} \mathrm{~S}_{\mathrm{SO} 4}$ values are reported with respect to the international standards V-SMOW and Vienna-Canyon Diablo Troilite (V-CDT). The analytical precisions for $\delta^{18} \mathrm{O}_{\mathrm{SO} 4}$ and $\delta^{34} \mathrm{~S}_{\mathrm{SO} 4}$ values were $\pm 0.5 \%$ and $\pm 0.3 \%$, respectively. 


\section{Results}

The analytical results of the chemical and isotopic measurements of surface and groundwater from the Pecos River are listed in Table 1 . There are wide variations in water chemistry and stable isotope geochemistry parameters of river water. The concentrations of $\mathrm{Cl}^{-}$and $\mathrm{SO}_{4}^{2-}$ of river water increased rapidly from $3 \mathrm{mg} / \mathrm{L}$ and $12 \mathrm{mg} / \mathrm{L}$ near Pecos in the mountainous headwater region to $79 \mathrm{mg} /$ $\mathrm{L}$ and $1362 \mathrm{mg} / \mathrm{L}$ near Santa Rosa and to $2298 \mathrm{mg} / \mathrm{L}$ and $1800 \mathrm{mg} / \mathrm{L}$ near Pierce Canyon Crossing. $\delta^{18} \mathrm{O}$ and $\delta \mathrm{D}$ values of river water increased progressively from $-12.7 \%$ and $-89.6 \%$ near Pecos to 5.0 and $11.5 \%$ near Malaga. The deuterium excess $(d)$, defined as $d=\delta \mathrm{D}-8 \delta^{18} \mathrm{O}$ (Dansgaard, 1964), decreased considerably (from $12 \%$ to $-2.5 \%$ ) from the upper basin downward.

Sulfur and oxygen isotope ratios of dissolved sulfates were different in the upper and lower basins of the Pecos River (Fig. 2a and b). $\delta^{18} \mathrm{O}_{\mathrm{SO} 4}$ and $\delta^{34} \mathrm{~S}_{\mathrm{SO}}$ values were +1.0 and $-6.2 \%$ at the initial sampling site near Pecos but increased concurrently with flow distance in the upper Pecos River. In the lower basin, however, $\delta^{34} \mathrm{~S}_{\mathrm{SO} 4}$ values were constant with $11.8 \pm 0.3 \%$ o while $\delta^{18} \mathrm{O}_{\mathrm{SO} 4}$ values decreased considerably from $14.1 \%$ near Santa Rosa to $9.0 \%$ near Pierce Canyon Crossing. $\Delta^{18} \mathrm{O}$ is the difference between $\delta^{18} \mathrm{O}$ of sulfate and $\delta^{18} \mathrm{O}$ of water (i.e., $\Delta^{18} \mathrm{O}=\delta^{18} \mathrm{O}_{\mathrm{SO} 4}$ $\left.\delta^{18} \mathrm{O}_{\mathrm{H} 2 \mathrm{O}}\right) \cdot \Delta^{18} \mathrm{O}$ values were relatively low in the upper basin, increasing from $13.7 \%$ o near Pecos to $16.3 \%$ onear Dilia, reaching their maximum of $24 \%$ o near Santa Rosa, and subsequently decreasing progressively to $14 \%$ in the Malaga and Pierce Canyon Crossing area (Fig. 2c).

Groundwater from the Roswell Basin is brackish with sulfate being the dominant anion (Table 1). There are two major aquifers in this basin, the alluvial aquifer and the Artesian aquifer. Water from the alluvial aquifer has higher concentrations of $\mathrm{Cl}^{-}$and $\mathrm{SO}_{4}^{2-}$, lower values of $\delta^{18} \mathrm{O}_{\mathrm{SO} 4}(9.5 \%), \delta^{34} \mathrm{~S}_{\mathrm{SO} 4}(11.6 \%)$ and $\Delta^{18} \mathrm{O}(17.1 \%) . \delta^{18} \mathrm{O}(-7.6 \%)$ and $\delta \mathrm{D}(-53.3 \%)$ values of water from the alluvial aquifer are similar to those of the Artesian aquifer $\left(\delta^{18} \mathrm{O}=-7.7 \%\right.$ ond $\delta \mathrm{D}=-55 \%$ 。).

\section{Discussion}

\subsection{Delivery of water and dissolved sulfate}

Water chemistry and stream discharge of the Pecos River fluctuate considerably from reach to reach (Fig. 3). On the basis of daily stream

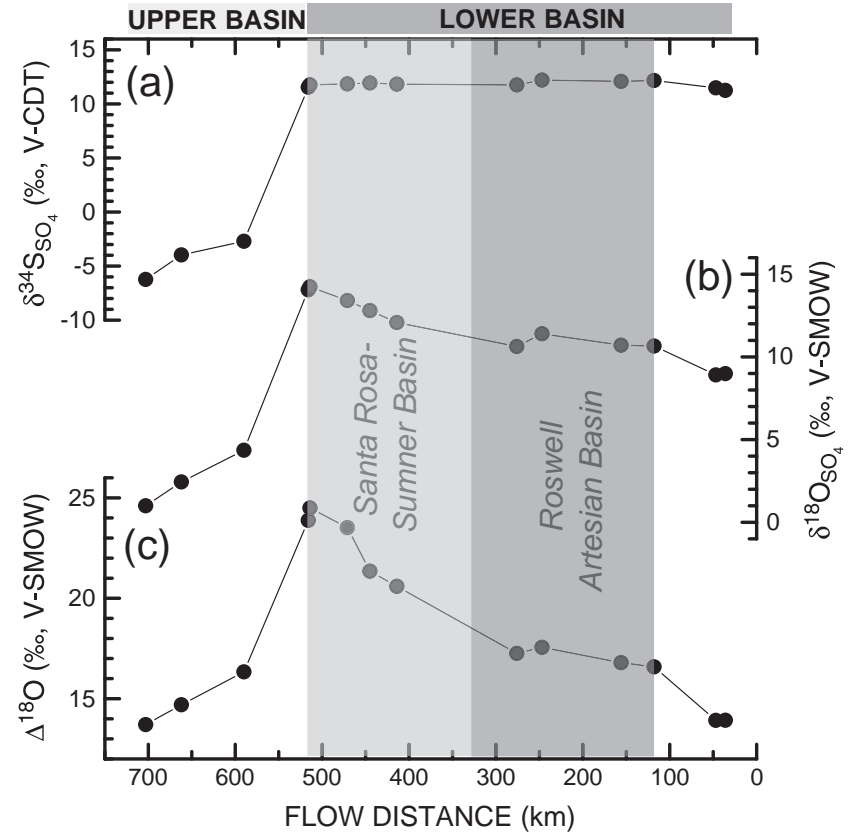

Fig. 2. Changes in oxygen and sulfur isotopic composition of surface water along the Pecos River. (a) $\delta^{34} \mathrm{~S}_{\mathrm{SO} 4 \cdot}$ (b) $\delta^{18} \mathrm{O}_{\mathrm{SO} 4 \cdot}$ (c) $\Delta^{18} \mathrm{O}$. Vertical gray bars highlight stable isotopic changes in the Santa Rosa-Sumner basin and the Roswell basin. $\Delta^{18} \mathrm{O}=\delta^{18} \mathrm{O}_{\mathrm{SO} 4}-\delta^{18} \mathrm{O}$. Flow distance to the river mouth near the New Mexico/Texas state line is estimated using Google Earth.

flow measurements from USGS gaging stations over the last decade (2001-2010), the annual average discharge of the river increased slightly from $2.5 \mathrm{~m}^{3} / \mathrm{s}$ near Pecos to $2.8 \mathrm{~m}^{3} / \mathrm{s}$ near Anton Chico, and then decreased to $2.4 \mathrm{~m}^{3} / \mathrm{s}$ at the gaging station above Santa Rosa Lake even though the river receives additional water from the Gallinas River at an annual average flow rate of $0.36 \mathrm{~m}^{3} / \mathrm{s}$. As documented previously (Harrington, 1957; Dinwiddie and Clebsch, 1973; Risser, 1987), a substantial amount of the river water infiltrates underground before reaching Santa Rosa Lake and comes back to surface in the reach between Santa Rosa and Puerto De Luna. The annual average discharge of the river peaks at Puerto De Luna $\left(4.3 \mathrm{~m}^{3} / \mathrm{s}\right)$ due to

Table 1

Analytical results of chemical and isotopic compositions of surface and groundwaters from the Pecos River, New Mexico.

\begin{tabular}{|c|c|c|c|c|c|c|c|c|c|c|c|}
\hline $\begin{array}{l}\text { Sample } \\
\text { ID }\end{array}$ & $\begin{array}{l}\text { Site } \\
\text { description }\end{array}$ & $\begin{array}{l}\text { Latitude } \\
\left({ }^{\circ} \mathrm{N}\right)\end{array}$ & $\begin{array}{l}\text { Longitude } \\
\left({ }^{\circ} \mathrm{W}\right)\end{array}$ & $\begin{array}{l}\mathrm{Cl}^{-} \\
(\mathrm{mg} / \mathrm{L})\end{array}$ & $\begin{array}{l}\mathrm{SO}_{4}^{2-} \\
(\mathrm{mg} / \mathrm{L})\end{array}$ & $\begin{array}{l}\delta \mathrm{D} \\
(\%, \mathrm{SMOW})\end{array}$ & $\begin{array}{l}\delta^{18} \mathrm{O} \\
(\% \text {, SMOW })\end{array}$ & $\begin{array}{l}\delta^{34} \mathrm{~S}_{\mathrm{SO} 4} \\
(\%, \mathrm{CDT})\end{array}$ & $\begin{array}{l}\delta^{18} \mathrm{O}_{\mathrm{SO} 4} \\
(\% \text {, SMOW })\end{array}$ & $\begin{array}{l}d^{\mathrm{a}} \\
(\%, \mathrm{SMOW})\end{array}$ & $\begin{array}{l}\Delta^{18} \mathrm{O}^{\mathrm{b}} \\
(\%, \text { SMOW })\end{array}$ \\
\hline \multicolumn{12}{|c|}{ Surface water } \\
\hline PR01 & Pecos & 35.576 & 105.670 & 3 & 12 & -89.6 & -12.7 & -6.2 & 1.0 & 12.1 & 13.7 \\
\hline PR02 & San Jose & 35.400 & 105.475 & 3 & 12 & -86.4 & -12.3 & -4.0 & 2.4 & 11.7 & 14.7 \\
\hline PR03 & Dilia & 35.171 & 105.049 & 3 & 14 & -86.2 & -12.0 & -2.7 & 4.4 & 9.6 & 16.3 \\
\hline PR04 & Santa Rosa & 34.939 & 104.691 & 79 & 1362 & -71.9 & -9.8 & 11.5 & 14.1 & 6.7 & 23.9 \\
\hline PR05 & Puerto De Luna & 34.827 & 104.626 & 129 & 1474 & -72.8 & -10.1 & 11.9 & 13.4 & 8.0 & 23.5 \\
\hline PR06 & S. Santa Rosa & 34.932 & 104.679 & 75 & 1430 & -75.0 & -10.3 & 11.8 & 14.2 & 7.0 & 24.5 \\
\hline PR07 & Sumner Lake & 34.605 & 104.388 & 93 & 1117 & -65.1 & -8.6 & 11.9 & 12.8 & 3.3 & 21.4 \\
\hline PR08 & Fort Sumner & 34.473 & 104.260 & 112 & 1107 & -65.0 & -8.5 & 11.8 & 12.1 & 3.1 & 20.6 \\
\hline PR09 & Acme & 33.572 & 104.374 & 346 & 1273 & -55.5 & -6.6 & 11.8 & 10.6 & -2.5 & 17.3 \\
\hline PR10 & Roswell & 33.397 & 104.398 & 1404 & 1714 & -51.9 & -6.2 & 12.2 & 11.4 & -2.6 & 17.6 \\
\hline PR15 & Artesia & 32.803 & 104.324 & 1746 & 1885 & -49.0 & -6.1 & 12.1 & 10.7 & -0.3 & 16.8 \\
\hline PR16 & Brantley Lake & 32.544 & 104.367 & 1019 & 1525 & -48.6 & -5.9 & 12.2 & 10.7 & -1.2 & 16.6 \\
\hline PR18 & Malaga & 32.323 & 104.032 & 2064 & 1770 & -42.5 & -5.0 & 11.5 & 8.9 & -2.4 & 13.9 \\
\hline PR19 & $\mathrm{PCC}^{\mathrm{C}}$ & 32.190 & 103.978 & 2298 & 1800 & -42.0 & -4.9 & 11.2 & 9.0 & -2.5 & 13.9 \\
\hline \multicolumn{12}{|c|}{ Groundwater } \\
\hline PR11 & Artesian aquifer & 32.755 & 104.387 & 34 & 878 & -52.0 & -7.0 & 13.3 & 11.5 & 3.7 & 18.4 \\
\hline PR12 & Artesian aquifer & 32.750 & 104.378 & 117 & 1400 & -58.0 & -8.4 & 13.1 & 10.6 & 9.2 & 18.9 \\
\hline PR13 & Alluvial aquifer & 32.755 & 104.360 & 256 & 1913 & -53.3 & -7.5 & 11.5 & 9.2 & 6.4 & 16.6 \\
\hline PR14 & Alluvial aquifer & 32.744 & 104.379 & 370 & 2139 & -53.4 & -7.7 & 11.8 & 9.9 & 7.9 & 17.6 \\
\hline
\end{tabular}

$\mathrm{a}=\delta \mathrm{D}-8 \delta^{18} \mathrm{O}$

b $\Delta^{18} \mathrm{O}=\delta^{18} \mathrm{O}_{\mathrm{SO} 4}-\delta^{18} \mathrm{O}$.

c Pierce Canyon Crossing. 


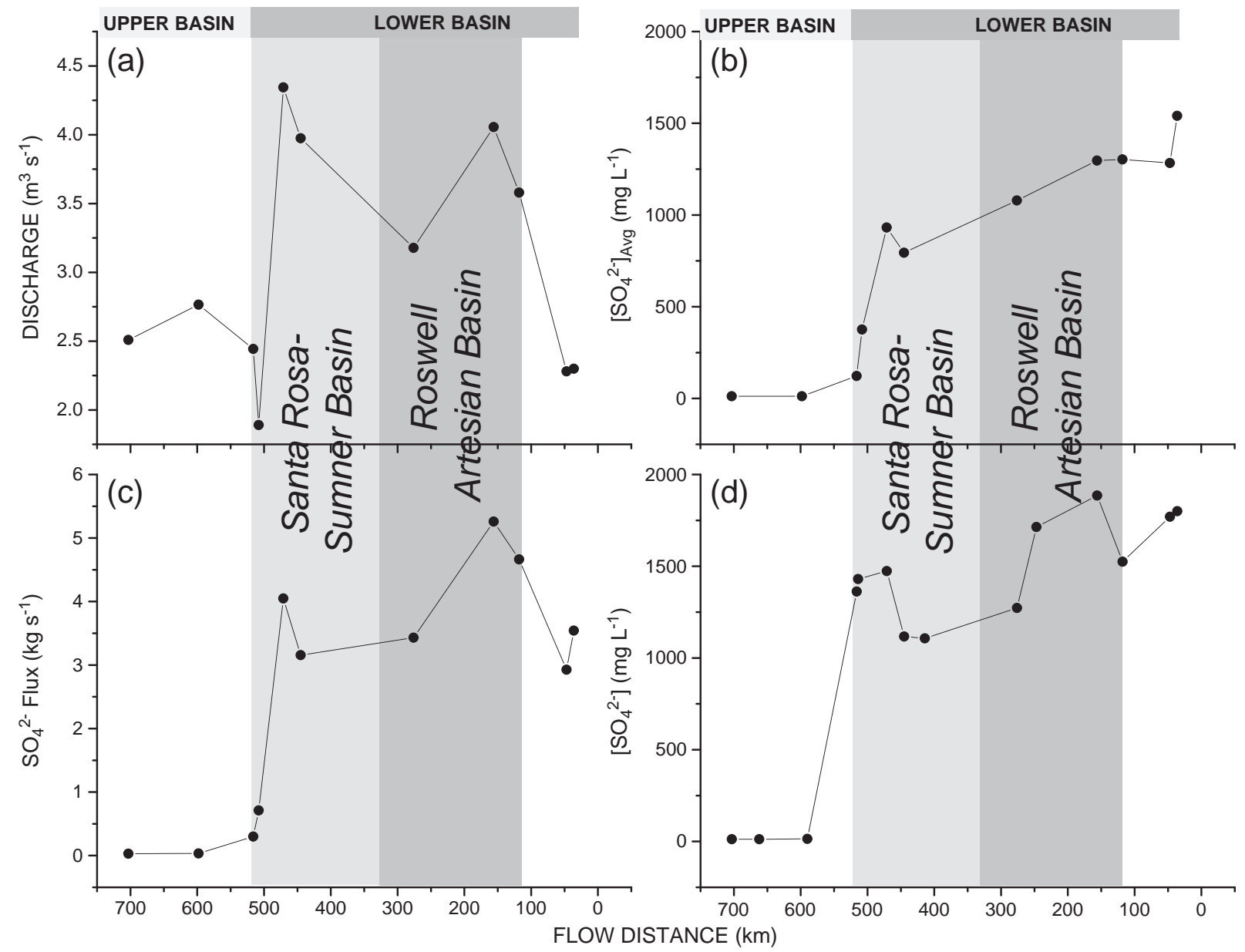

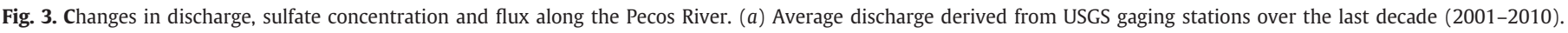

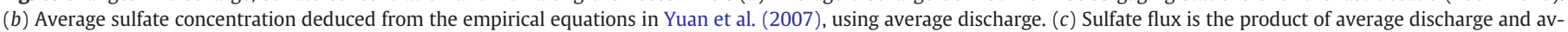

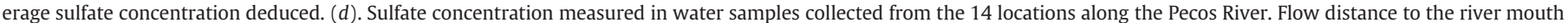

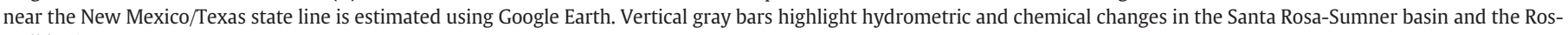
well basin.

the additions of groundwater (Harrington, 1957) and decreases significantly (by 27\%) in the reach between Puerto De Luna and Acme. The observed flow decrease in this reach is caused primarily by evaporative water loss in Sumner Lake and the water diversion for irrigation purposes in the FSID (Longworth and Carron, 2003). In the reach along the eastern margin of the Roswell Basin, the Pecos River gains significantly $(23 \%)$ from various spring flows. Earlier studies documented a substantial amount $\left(5 \mathrm{~m}^{3} / \mathrm{s}\right)$ of spring water flowing into the river near Roswell (Fiedler and Nye, 1933; Theis, 1965). Today the amount of spring water contributing to the river is considerably reduced due to extensive groundwater withdrawal for irrigation practices in the PVACD. The average discharge of the river decreased from $4.1 \mathrm{~m}^{3} / \mathrm{s}$ near Artesia to $2.3 \mathrm{~m}^{3} / \mathrm{s}$ near the Malaga Bend and Pierce Canyon Crossing area due to evaporative water loss in Brantley Lake and Lake Avalon, and the water diversion by the CID. River water in the Malaga and Pierce Canyon Crossing area consists of reservoir water from Lake Avalon, agricultural returnflows, and saline groundwater seepages (Hale et al., 1954; Havens and Wilkins, 1980; Yuan and Miyamoto, 2005; Yuan et al., 2007).

There exists a significant log-linear correlation of stream discharge and sulfate concentration at most gaging stations of the Pecos River (Yuan et al., 2007). The average concentrations of dissolved sulfate at various gaging stations on the Pecos River can be calculated using the empirical log-linear equations tabulated in Yuan et al. (2007, Table 3 ) and the average discharge over the last decade (Fig. 3a and b). The new measurements of dissolved sulfate reported in this study are consistent with those derived from the empirical equations (cf. Fig. 3b and d). Concentrations of dissolved sulfate in river water increase abruptly between the upper basin and the lower basin, most prominently in the reach between Santa Rosa and Puerto De Luna. But there are some discrepancies between the two curves, e.g., the significant increases in sulfate concentration in the reach adjacent to the Roswell Basin (Fig. 3d). This may be explained by a pronounced effect of spring water during non-irrigation low flow conditions when water samples were taken in March 2010.

Accordingly, the sulfate flux of the Pecos River fluctuates widely from reach to reach. Most of dissolved sulfate additions occur in the two areas, i.e., the Santa Rosa basin and the Roswell basin, as highlighted in Fig. 3c. In contrast, there are some decreases in sulfate loading in the reaches associated with the two major reservoirs (Sumner Lake and Lake Brantley), and in the Malaga Bend area. Considering the changes in sulfate fluxes (Fig. 3c) and drainage area from USGS (2010), the sulfate export rates of the river change considerably from $5.4 \mathrm{~kg} \mathrm{~S} / \mathrm{ha} / \mathrm{yr}$ in the upper basin to $74 \mathrm{~kg} \mathrm{~S} / \mathrm{ha} / \mathrm{yr}$ in the Santa Rosa basin to $3.9 \mathrm{~kg} \mathrm{~S} / \mathrm{ha} / \mathrm{yr}$ in the Roswell basin to $-37 \mathrm{~kg} \mathrm{~S} / \mathrm{ha} / \mathrm{yr}$ in the Carlsbad basin. The relatively high export rate from the Santa Rosa basin is due to the dissolution of Permian evaporites (Yuan and Miyamoto, 2005) while the relatively low or even negative export rates of the Roswell and Carlsbad basins may be associated with land use activities. 


\subsection{Chemical and isotopic characteristics of river water}

The analysis of chemical and isotopic compositions of river water has proven useful for the identification of water sources and flow pathways in the Pecos River (Yuan and Miyamoto, 2008). $\delta^{18} \mathrm{O}$ and $\delta \mathrm{D}$ values of river water in the Pecos River increase progressively from the upper basin downward (Fig. 4a and b). There are two positive isotopic excursions in the reaches between the Santa Rosa basin and the Roswell basin, indicating a pronounced isotopic enrichment of deuterium and ${ }^{18} \mathrm{O}$ induced by enhanced evaporation from openwater surfaces in lakes and wetlands and agricultural farmlands in the two basins. Moreover, $\delta^{18} \mathrm{O}$ and $\delta \mathrm{D}$ values of river water from the lower Pecos River fall slightly below the global meteoric water line (GMWL, $\delta \mathrm{D}=8 \delta^{18} \mathrm{O}+10$ ) (Craig, 1961) and form a local river water line (LRWL, $\left.\delta D=6.0 \delta^{18} \mathrm{O}-13.4\right)$. The observed deviation from the GMWL usually reflects a differential isotopic enrichment of ${ }^{18} \mathrm{O} /{ }^{16} \mathrm{O}$ relative to $\mathrm{D} / \mathrm{H}$ in the remaining water during evaporation (e.g., Cappa et al., 2003; Yuan and Miyamoto, 2008).

The d-excess $(d)$ is defined as $d=\delta \mathrm{D}-8 \delta^{18} \mathrm{O}$, which is the intercept of the GMWL (Dansgaard, 1964). As pointed out in Yuan and Miyamoto (2008), $d$ is a better indicator of evaporation-induced heavy isotopic enrichment than either $\delta^{18} \mathrm{O}$ or $\delta \mathrm{D}$. This is not only because $d$ is controlled by both $\delta^{18} \mathrm{O}$ and $\delta \mathrm{D}$ but also because the average $d$ values of precipitation are more or less constant $(\sim 10 \%)$ in many areas around the world. In the Pecos River, the $d$ values of river water decrease from $12.1 \%$ near Pecos to $-2.5 \%$ at Pierce Canyon Crossing (Fig. 4c), indicating a cumulative effect of evaporation with increasing flow distance downstream. There are, however, two positive excursions occurring in the Santa Rosa basin and the Roswell basin, indicating some groundwater discharge into the river water.

Assuming there is an insignificant amount of water inputs from local precipitation and water loss through evaporation, the relative contribution of groundwater additions over the total river flow may be estimated by a simple d-excess based binary model (Yuan and Miyamoto, 2008).

$f=\frac{d_{d}-d_{u}}{d_{g}-d_{u}}$

where

$d_{u} \quad$ is the $d$-excess of river water upstream

$d_{d} \quad$ is the $d$-excess of river water downstream

$d_{g} \quad$ is the $d$-excess of local groundwater additions

$f \quad$ is the fraction of local groundwater additions

To determine the fraction of local groundwater additions to the Pecos River near the Roswell basin, we assigned $d_{u}=-2.6 \%$, the average $d$ value of river water at the reach between Acme and Roswell (upstream), $d_{d}=-0.3 \%$, the $d$ value of the river water at Artesia (Table 1). The average $d$ value of groundwater samples from the alluvial aquifer and the Artesian aquifer near the Agricultural Science Center of NMSU at Artesia (excluding sample PR11 from a water

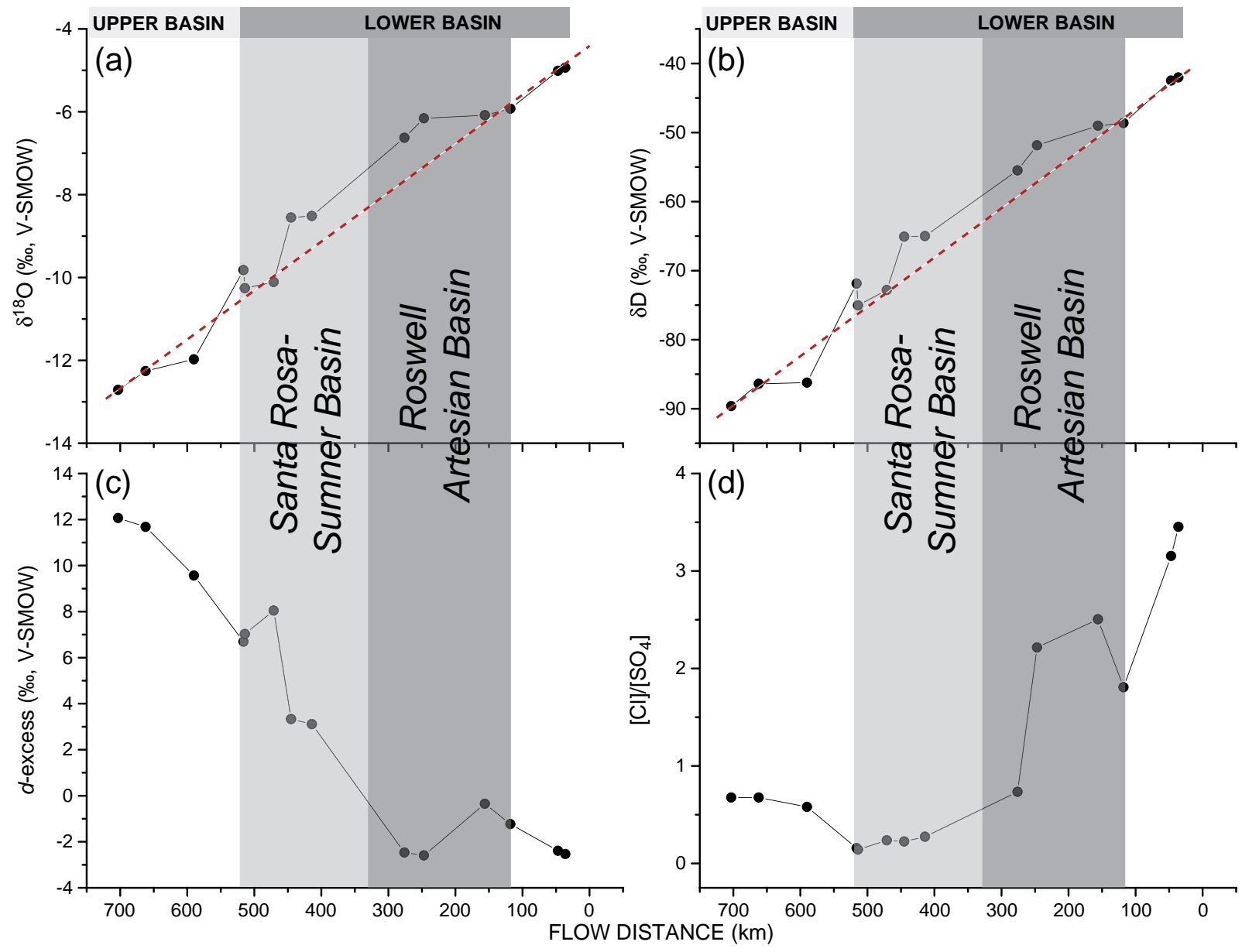

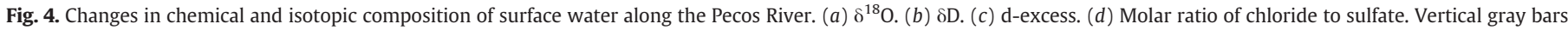

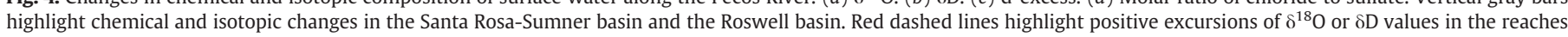
between the Santa Rosa basin and the Roswell basin. 
storage pond affected by evaporation) is $8 \%$, slightly lower than the average $d$ values (9\%) of groundwater samples from the TransPecos and the Roswell basins (Hoy and Gross, 1982; Uliana et al., 2007). The average $d$ value of spring waters near Roswell is $10.7 \%$ 。 (Land and Huff, 2010). Thus, it is tempting to assign $d_{g}=9 \%$, the average $d$ value of groundwater samples from the Roswell basin, as the $d$ value for local groundwater additions. Using this deduced $d_{g}$ value, we calculated the fraction of local groundwater additions over the total stream flow in the river to be around $20 \%$. This \% value (i.e., the calculated fraction) is slightly lower than that of the annual average flow gain (23\%) in the reach between Acme and Artesia over the last decade, as estimated above. Similarly, the fraction of groundwater discharge into the reach between the Santa Rosa and Puerto De Luna is estimated around 39\%, if assuming $d_{g}=10 \%$ o as the $d$ value for local groundwater. The average flow gain in the Santa Rosa basin over the last decade is $56 \%$ (Fig. 3a). The discrepancy suggests that the groundwater additions in this reach contain a significant amount of surface water from upstream reaches. Although uncertainties remain, the simple $d$-based binary modeling may serve as an independent approach for the separation, quantification and/or validation of the amount of water gains or losses in a specific river reach.

\subsection{Sulfur sources and cycling in the upper basin}

The isotopic composition of dissolved sulfate can serve as an indicator of sulfur sources and transformations in a watershed (e.g., Caron et al., 1986; Berner et al., 2002; Shanley et al., 2005; Rock and Mayer, 2009). On global scales, $\delta^{34} \mathrm{~S}_{\mathrm{SO} 4}$ and $\delta^{18} \mathrm{O}_{\mathrm{SO} 4}$ values of atmospheric deposition vary greatly, ranging from -3 to $9 \%$ and from 7 to $17 \%$ in many industrialized countries (Krouse and Mayer, 2000). The average $\delta^{34} \mathrm{~S}_{\mathrm{SO} 4}$ and $\delta^{18} \mathrm{O}_{\mathrm{SO} 4}$ values of atmospheric deposition in southern California and southern Nevada are $5.8 \pm 1.4 \%$ and $11.2 \pm 1.9 \%$ (Bao and Reheis, 2003). In northern New Mexico, $\delta^{34} \mathrm{~S}_{\mathrm{SO} 4}$ values of meteoric waters (rain, snow, and lake water) range from 3.0 to $4.2 \%$ o (Lynch et al., 1988; Mast et al., 2001). $\delta^{18} \mathrm{O}_{\mathrm{SO} 4}$ values of Colorado Rockies precipitation sulfate range from 10 to $15 \%$ o (Kester et al., 2003; Scanlon et al., 2009). Atmospheric sulfate undergoes a series of processes in the soil zone, including assimilatory sulfate reduction by plants and microbes and oxidation and mineralization of organic sulfur. The latter processes cause a decrease of over $5 \%$ compared to the $\delta^{18} \mathrm{O}_{\mathrm{SO} 4}$ of atmospheric sulfate, since new oxygen atoms are introduced into the newly formed sulfate while there is little change in the ${ }^{34} \mathrm{~S}_{\mathrm{SO} 4}$ (Mayer et al., 1995a; Mayer et al., 1995b; Shanley et al., 2005). Thus, the average $\delta^{34} \mathrm{~S}$ and $\delta^{18} \mathrm{O}$ values of atmospheric-derived sulfate that has been recycled in the soil zone in this watershed are estimated to be $3.5 \%$ and $7.5 \%$ ( Fig. $5 \mathrm{~d}$ ), significantly higher than the measured values of river water sulfate from the upper Pecos River. This indicates that atmospheric deposition is not the only source of sulfate present in river water.

In fact, oxidation of sulfide minerals in the Pecos mine drainage near Tererro, New Mexico, has contributed to an elevated concentration $(>100 \mathrm{mg} / \mathrm{L})$ of dissolved sulfate in Willow Creek, a tributary to the upper Pecos River (Berger et al., 2000). $\delta^{34}$ S values of sulfide deposits from the Questa mine in northern New Mexico vary greatly from -13.5 to $0.5 \%$ (Campbell and Lueth, 2008). $\delta^{34} \mathrm{~S}_{\mathrm{SO} 4}$ and $\delta^{18} \mathrm{O}_{\mathrm{SO} 4}$ values of alteration scars from the Questa mine range from -10.6 to $0 \%$ and from -3 to $3 \%$, respectively (Campbell and Lueth, 2008). Although not derived from the Pecos mine drainage, these data place an important range of isotopic variability for sulfates in this region. It is particularly useful to estimate the average $\delta^{18} \mathrm{O}_{\mathrm{SO} 4}$ value of the Pecos mine drainage as it depends largely on local climatic and drainage conditions (Taylor and Wheeler, 1993). As a first approximation of the relative contributions from the Pecos mine drainage we assigned $0 \%$ as the average $\delta^{18} \mathrm{O}_{\text {so }}$ value and deduced $\delta^{34} \mathrm{~S}_{\mathrm{SO} 4}=-7.8 \%$ for sulfide oxidation-derived sulfate in this watershed by linear extrapolation (Fig. 5d).
Once $\delta^{34} \mathrm{~S}_{\mathrm{SO} 4}$ and $\delta^{18} \mathrm{O}_{\mathrm{SO} 4}$ values of the two end-members of atmospheric deposition and acid mine drainage are assigned, their relative contributions to the pool of stream sulfate in the watershed can be quantified using a simple binary mixing model. Our calculations indicate that sulfate from the Pecos mine drainage accounts for $86 \%$ and $67 \%$ of the total dissolved sulfate in river water near Pecos and San Jose, respectively. This indicates that the majority of the stream sulfate at the two sites is from oxidation of sulfide minerals in the upper Pecos valley. However, stream sulfate of river water near Dilia is influenced by the occurrence of Permian evaporites because the isotopic data point corresponding with this site lies significantly above the mixing line between sulfide oxidation and soil sulfate end-members (Fig. 5d). The gypsum-bearing Bernal Formation prevailing in the Santa Rosa basin has a northwestern limit near the Bernal and Villanueva area (Lucas, 1991).

\subsection{Sulfur sources and cycling in the lower basin}

The lower Pecos River flows across the Permian basin in eastern New Mexico and receives dissolved salts from the dissolution of ancient evaporites (halite, anhydrite, and gypsum) (Van Denburgh and Feth, 1965; Hiss et al., 1969; Johnson, 1981; Yuan and Miyamoto, 2005). $\delta^{34} \mathrm{~S}_{\text {SO4 }}$ values of river water from the lower basin are quite constant with an average value of $11.8 \%$, almost identical to those of shallow groundwater from the alluvial aquifer but slightly lower than those of deep groundwater from the Artesian aquifer (Fig. 5d). All the $\delta^{34} \mathrm{~S}_{\mathrm{SO} 4}$ values of river and groundwater samples are within the range of $\delta^{34} \mathrm{~S}_{\mathrm{SO} 4}$ values (10.5 to $13.8 \%$ ) of Permian evaporites from Salado, Castile, and San Andres Formations in this region (Claypool et al., 1980). Moreover, the average $\delta^{34} S_{\text {SO4 }}$ value $(11.8 \%$ ) of river water from the lower Pecos River is identical to that of groundwater from the San Andres aquifer in the middle Rio Grande basin (Plummer et al., 2004). $\delta^{34} \mathrm{~S}_{\mathrm{SO} 4}$ values of the deep groundwater are slightly elevated due to bacterial (dissimilatory) sulfate reduction as indicated by the presence of the distinctive smell of hydrogen sulfide $\left(\mathrm{H}_{2} \mathrm{~S}\right)$.

In contrast, $\delta^{18} \mathrm{O}_{\mathrm{SO} 4}$ values of river water decrease considerably from the Santa Rosa basin to the Roswell basin (Figs. 2b and 5d). Stream sulfate from the Santa Rosa basin has the highest values of $\delta^{18} \mathrm{O}_{\mathrm{SO} 4}\left(14 \%\right.$ ) found in river water, exceeding the maximal $\delta^{18} \mathrm{O}_{\mathrm{SO} 4}$ value $(12.2 \%$ ) of Permian evaporites previously documented in this region (Claypool et al., 1980). Although two major sulfate-bearing units (Bernal Formation and San Andres Formation) are documented in the Santa Rosa basin (Risser, 1987), the higher $\delta^{18} \mathrm{O}_{\mathrm{SO} 4}$ value of river water suggests that the stream sulfate is largely derived from the Bernal Formation. This is because groundwater samples from the Artesian aquifer (i.e., San Andres Formation) have lower $\delta^{18} \mathrm{O}_{\mathrm{SO} 4}$ values $(\sim 11 \%$ o). Like atmospheric sulfate deposition, stream sulfate derived from Permian evaporites undergoes sulfur cycling and transformation processes. For example, there is a $3.5 \%$ decrease in $\delta^{18} \mathrm{O}_{\mathrm{SO} 4}$ of river water in the section between Santa Rosa and Acme. Assuming the average $\delta^{18} \mathrm{O}$ value of recycled sulfate is $6 \%$, the average $\delta^{18} \mathrm{O}_{\mathrm{SO} 4}$ value of soil extracts from the southern High Plains (Scanlon et al., 2009), we estimated that $43 \%$ of dissolved sulfate has been recycled in the Santa Rosa and Sumner basin. In the Roswell basin, however, the Pecos River receives additional dissolved sulfate from spring waters as discussed above. The positive excursion, as highlighted in Fig. 2b, indicates that the $\delta^{18} \mathrm{O}_{\mathrm{SO} 4}$ values of spring inputs are higher than those of river water near Acme. The average $\delta^{18} \mathrm{O}_{\mathrm{SO} 4}$ value of spring water was calculated to be $12.9 \%$ by a binary mixing model, using values of sulfate flux and $\delta^{18} \mathrm{O}_{\mathrm{SO} 4}$ of river water. The estimated $\delta^{18} \mathrm{O}_{\mathrm{SO} 4}$ value is slightly higher than that of river and groundwater samples collected and measured in this area. The chemical and isotopic compositions of spring water near Roswell are significantly different from those of the groundwater near Artesia. Besides, there is a minimal $\left(0.7 \%\right.$ ) decrease in $\delta^{18} \mathrm{O}_{\mathrm{SO} 4}$ of river water in the reach 

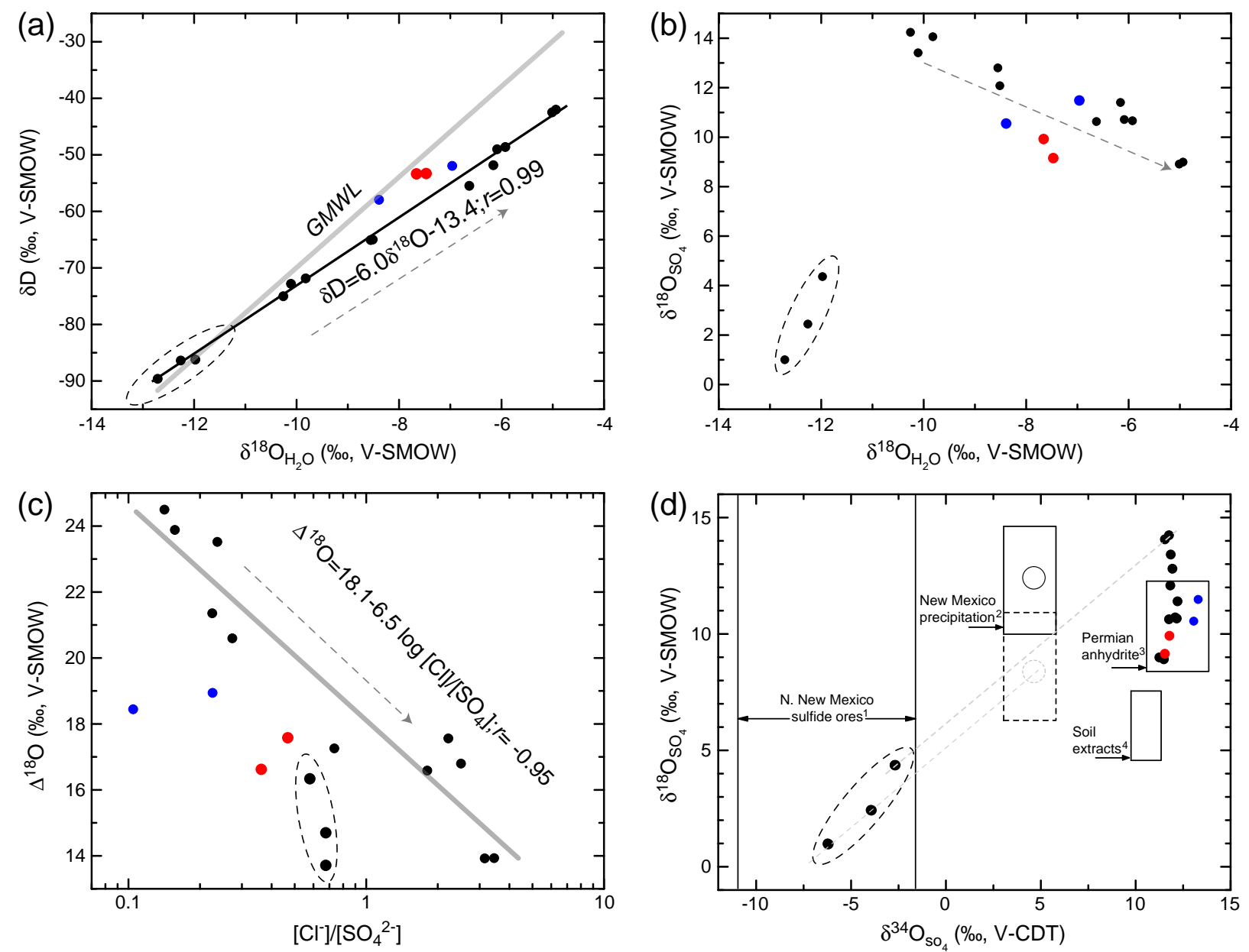

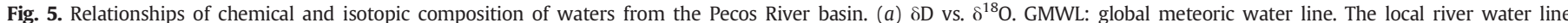

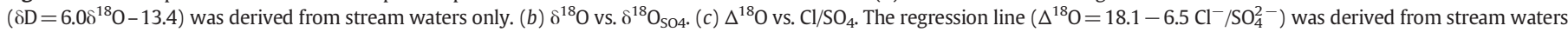

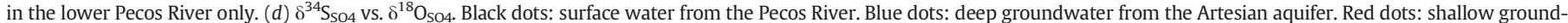

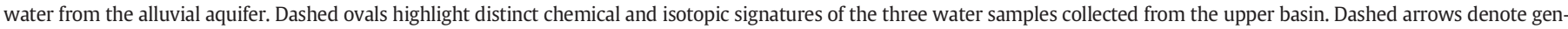

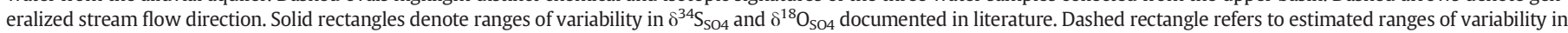

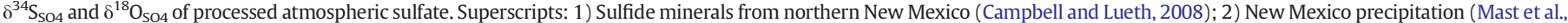
2001); 3) Permian evaporites (Claypool et al., 1980); 4) Soil extracts from the Southern High Plains (Scanlon et al., 2009). $\Delta^{18} \mathrm{O}=\delta^{18} \mathrm{O}_{\mathrm{SO}}-\delta^{18} \mathrm{O}$.

between Roswell and Brantley Lake. This may indicate that about 13\% of dissolved sulfate has been recycled. Lastly, there is a $1.7 \%$ o decrease in $\delta^{18} \mathrm{O}_{\mathrm{SO} 4}$ of river water in the reach between Brantley Lake and Pierce Canyon Crossing, indicating $37 \%$ of dissolved sulfate has been recycled. In summary, a total of $63 \%$ of dissolved sulfate in river water might have been recycled to account for the observed $5 \%$ o decrease in $\delta^{18} \mathrm{O}_{\mathrm{SO} 4}$ across the lower basin. It is noted that some of the decrease in $\delta^{18} \mathrm{O}_{\mathrm{SO} 4}$ values observed may be attributed to variations in $\delta^{18} \mathrm{O}_{\mathrm{SO} 4}$ of Permian evaporites in the basin and would lead to some uncertainties in the calculations. Nevertheless, our calculations suggest that the rate of sulfur cycling could change significantly from reach to reach in the lower Pecos River.

\subsection{Influence of land use on sulfur cycling and transport}

It has been shown that the rate of dissolved salt export from the Pecos River fluctuates over time due to changes in land use and climatic conditions (Yuan et al., 2007). Groundwater withdrawal, reservoir operation, and agricultural returnflows affect the rate of dissolved salt accumulation on farmlands in the region. There are three major irrigation districts (i.e., FSID, PVACD, and CID) in the Pecos River basin (Fig. 1). FSID and CID divert water from the Pecos
River at average rates of 1.5 and $2.9 \mathrm{~m}^{3} / \mathrm{s}$ while PVACD pumps water mostly from the two major aquifers at a rate of $11.7 \mathrm{~m}^{3} / \mathrm{s}$ (Longworth and Carron, 2003; Wilson et al., 2003; Longworth et al., 2008). Irrigation water withdrawal by FSID has little effect on sulfate flux in the river while flow diversion by CID leads to a considerable reduction in sulfate flux in the river. Because of the proximity to the river, sulfates accumulated on the FSID irrigated farmlands are readily washed out into the river. We estimated that about $37 \%$ of riverine dissolved sulfate is transferred onto farmlands during irrigation seasons. More than half of dissolved sulfate accumulated is flushed back to the river without soil processing because only $43 \%$ of dissolved sulfate has been recycled from the observed changes in $\delta^{18} \mathrm{O}_{\mathrm{SO} 4}$ of river water. On the contrary, about $82 \%$ of riverine sulfate is transferred by CID onto irrigated farmlands and only $76 \%$ of the accumulated sulfate returns to the river by agricultural drains (Fig. 3c). As a result, irrigation farmlands in CID serve as a sink of dissolved river sulfate. In the Roswell basin, groundwater withdrawal by PVACD members introduces $17.6 \mathrm{~kg} / \mathrm{s}$ ( or $55510^{6} \mathrm{~kg} / \mathrm{yr}$ ) of dissolved sulfate onto 40,000 ha farmlands. The sulfate flux from groundwater pumping is five times that observed in the Pecos River near Acme. Only $10 \%$ of the accumulated sulfate is exported to the river by spring flows and agricultural drains (Fig. 3c). The relatively low rate of 
sulfate export from irrigated farmlands may be due in part to the relatively dry conditions prevailing in the region over the last decade.

The influence of land use activities on sulfur cycling and delivery is significant but varies from one irrigation district to another in the Pecos River. To further evaluate the influence of land use on sulfur cycling, we examined variations in $\delta^{18} \mathrm{O}_{\mathrm{SO} 4}$ values in relation to changes in the molar ratio of chloride to sulfate and the $\delta^{18} \mathrm{O}$ value of river water. $\delta^{18} \mathrm{O}_{\mathrm{SO} 4}$ is positively correlated with $\delta^{18} \mathrm{O}$ in the upper Pecos River and negatively correlated with $\delta^{18} \mathrm{O}$ in the lower basin (Fig. 5b). While the positive correlation is probably induced by varying degrees of mixing among isotopically distinct end-members of sulfide-derived sulfate, atmospheric sulfate, and evaporite-dissolved sulfate in the upper Pecos River, the negative correlation may be caused by the cumulative additions of recycled sulfate (with significantly lower $\delta^{18} \mathrm{O}_{\mathrm{SO} 4}$ values) in the downstream portions of the basin. The oxygen isotope exchange between sulfate and water in natural environments is very slow, at timescales of at least $10^{5} \mathrm{yrs}$ (Lloyd, 1968), and usually considered insignificant due to a relatively short life span of dissolved sulfate in most near-surface environments (Van Stempvoort and Krouse, 1994). A plot of $\Delta^{18} \mathrm{O}$ vs. $\left.\left[\mathrm{Cl}^{-}\right] / \mathrm{SO}^{2-}\right]$ shows a separation of waters with different origins (Fig. 5c). Samples of groundwater and river water from the upper basin deviate significantly from the regression line derived from river waters in the lower basin. $\Delta^{18} \mathrm{O}$ values of river water from the Santa Rosa area are around $24 \%$, significantly higher than those of groundwater from the Roswell basin. This may signify variations in $\delta^{18} \mathrm{O}$ of dissolved sulfate from Permian evaporites in the two basins. The negative correlation between $\Delta^{18} \mathrm{O}$ and the molar ratio of chloride to sulfate in river water is interpreted to indicate the influence of land use on sulfur cycling and delivery. The molar ratio of chloride to sulfate of river water increases progressively due to a cumulative effect of land use, coinciding with decreases in $\delta^{18} \mathrm{O}_{\mathrm{SO} 4}$ due to sulfur cycling and increases in $\delta^{18} \mathrm{O}$ due to evaporation from the upper basin downward. There is a total of $10 \%$ o decrease in $\Delta^{18} \mathrm{O}$ in the lower Pecos River. Nearly half of that decrease is due to increases in $\delta^{18} \mathrm{O}$ of river water that resulted from evaporative enrichment. The other half is induced by decreases in $\delta^{18} \mathrm{O}_{\mathrm{SO} 4}$ of river water, most of which may be induced by sulfur cycling. It is evident that both sulfur cycling and evaporation can be enhanced by intensive land use activities. Thus, $\Delta^{18} \mathrm{O}$ may serve as an indicator of the extent of land use activities as it is related to evaporation, sulfur cycling, and relative accumulation of chloride to sulfate.

Interestingly, most of the $5 \%$ o decrease in $\delta^{18} \mathrm{O}_{\mathrm{SO}}$ values occurs in river reaches associated with the two small irrigation districts (CID and FSID). There is a minimal $\left(0.7 \%\right.$ o) decrease in $\delta^{18} \mathrm{O}_{\mathrm{SO} 4}$ of river reaches adjacent to the largest irrigation district (PVACD) in the Roswell basin. We speculate that some of the isotopic variations may be attributed to differences in agricultural practices. PVACD farmers depend exclusively on groundwater for irrigation while CID and FSID clients use surface water from the river for irrigation. Additionally, sulfate inputs from spring water near Roswell have a more positive $\delta^{18} \mathrm{O}_{\mathrm{SO} 4}$ value which may offset some of the decrease in $\delta^{18} \mathrm{O}_{\mathrm{SO} 4}$ caused by sulfur cycling.

\section{Conclusions}

Chemical and isotopic measurements of surface and groundwater samples were carried out to identify and quantify sulfur sources and cycling in different parts of the Pecos River. The results of this study show that surface waters from the river are characterized by a wide range of variations in water chemical and isotopic compositions, with $\mathrm{Cl}^{-}$ranging from 3 to $2298 \mathrm{mg} / \mathrm{L}, \mathrm{SO}_{4}^{2-}$ from 12 to $1885 \mathrm{mg} / \mathrm{L}$, $\delta \mathrm{D}$ from -89.6 to $-42.0 \%$, $\delta^{18} \mathrm{O}$ from -12.7 to $-4.9 \%$, $\delta^{34} \mathrm{~S}_{\mathrm{SO} 4}$ from -6.2 to $12.2 \%$, and $\delta^{18} \mathrm{O}_{\mathrm{SO} 4}$ from 1.0 to $14.2 \%$. Detailed analysis of the chemical and isotopic data allowed us to divide the Pecos River into an upper basin above Santa Rosa Lake and a lower basin above Red Bluff Reservoir. River water from the upper basin is characterized by low concentrations of $\mathrm{Cl}^{-}$and $\mathrm{SO}_{4}^{2-}$, low values of $\delta^{18} \mathrm{O}$ and $\delta \mathrm{D}$, and low values of $\delta^{18} \mathrm{O}_{\mathrm{SO} 4}$ and $\delta^{34} \mathrm{~S}_{\mathrm{SO} 4}$. Dissolved sulfate in the upper basin is from at least three different sources, namely the oxidation of sulfide minerals, the soil processing of atmospheric sulfate, and the dissolution of ancient evaporites. The dissolved sulfate from the oxidation of sulfides in the upper valley above Pecos has distinctively low values of $\delta^{18} \mathrm{O}_{\mathrm{SO} 4}$ and $\delta^{34} \mathrm{~S}_{\mathrm{SO} 4}$ while the dissolved sulfate from the dissolution of evaporites in the lower part of the basin has high values of $\delta^{18} \mathrm{O}_{\mathrm{SO} 4}$ and $\delta^{34} \mathrm{~S}_{\mathrm{SO} 4}$. The dissolved sulfate from the soil processing of atmospheric sulfate has intermediate $\delta^{18} \mathrm{O}_{\mathrm{SO} 4}$ and $\delta^{34} \mathrm{~S}_{\mathrm{SO} 4}$ values. The relative contributions of these end-members to the pool of stream sulfate in river water can be evaluated, using the $\delta^{18} \mathrm{O}_{\mathrm{SO} 4}$ and $\delta^{34} \mathrm{~S}_{\mathrm{SO} 4}$ values.

In the lower Pecos River, dissolved sulfate of river water is mainly from the dissolution of ancient evaporites. Despite lithologic variations, $\delta^{34} S_{\text {SO4 }}$ values of river water are rather constant throughout the lower basin, with an average value of $11.8 \%$, typical of $\delta^{34} \mathrm{~S}_{\mathrm{SO} 4}$ values of Permian evaporites found in this region (Claypool et al., 1980; Plummer et al., 2004). On the other hand, $\delta^{18} \mathrm{O}_{\text {sO4 }}$ values of river water decrease considerably due to sulfur cycling in the watershed. A $5 \%$ decrease in $\delta^{18} \mathrm{O}_{\mathrm{SO} 4}$ of river water in the lower Pecos River may indicate that $63 \%$ of the dissolved sulfate has been recycled in the watershed. Surprisingly, most of the sulfur cycling observed occurs in the two small irrigation districts (CID and FSID). There is little contribution to the decrease in $\delta^{18} \mathrm{O}_{\mathrm{SO} 4}$ of river water from the largest irrigation district (PVACD). The findings of this work imply that the influence of land use activities on sulfur cycling and transport may be more profound than previously thought.

\section{Acknowledgments}

We thank C. Fan and F. Contreras for their assistance in field sampling and M. Albert for sample processing. This work was partially supported by the US National Science Foundation (EAR-0902895) and by the Natural Sciences and Engineering Research Council of Canada (NSERC). We also want to acknowledge the support from Cleveland State University through Faculty Research Development Fund. Discussion with G. Lewis and R. Flynn is helpful for clarification of some important issues related to the use of water and fertilizer in the Pecos River basin.

\section{References}

Balci, N., Shanks, W.C., Mayer, B., Mandernack, K.W., 2007. Oxygen and sulfur isotope systematics of sulfate produced by bacterial and abiotic oxidation of pyrite. Geochimica et Cosmochimica Acta 71 (15), 3796-3811.

Bao, H., Reheis, M.C., 2003. Multiple oxygen and sulfur isotopic analyses on watersoluble sulfate in bulk atmospheric deposition from the southwestern United States. Journal of Geophysical Research 108 (4430). doi:10.1029/2002JD003022.

Berger, A.C., Bethke, C.M., Krumhansl, J.L., 2000. A process model of natural attenuation in drainage from a historic mining district. Applied Geochemistry 15 (5), 655-666.

Berner, Z.A., Stuben, D., Leosson, M.A., Klinge, H., 2002. S- and O-isotopic character of dissolved sulphate in the cover rock aquifers of a Zechstein salt dome. Applied Geochemistry 17 (12), 1515-1528.

Campbell, A.R., Lueth, V.W., 2008. Isotopic and textural discrimination between hypogene, ancient supergene, and modern sulfates at the Questa mine, New Mexico. Applied Geochemistry 23 (2), 308-319.

Cappa, C.D., Hendricks, M.B., DePaolo, D.J., Cohen, R.C., 2003. Isotopic fractionation of water during evaporation. Journal of Geophysical Research 108 (D16), 1-10.

Caron, F., Tessier, A., Kramer, J.R., Schwarcz, H.P., Rees, C.E., 1986. Sulfur and oxygen isotopes of sulfate in precipitation and lakewater, Quebec, Canada. Applied Geochemistry 1 (5), 601-606.

Claypool, G.E., Holser, W.T., Kaplan, I.R., Sakai, H., Zak, I., 1980. The age curves of sulfur and oxygen isotopes in marine sulfate and their mutual interpretation. Chemical Geology 28 (3-4), 199-260.

Craig, H., 1961. Isotopic variation in meteoric waters. Science 133 (3465), 1702-1703.

Dansgaard, W., 1964. Stable isotopes in precipitation. Tellus 16, 436-468.

Davies, B.R., Thoms, M.C., Walker, K.F., O'Keefe, J.H., Gore, J.A., 1996. Dryland rivers: their ecology conservation and management. In: Calow, P., Petts, G.E. (Eds.), The Rivers Handbook: Hydrological and Ecological Principles. Blackwell Science Ltd., Cambridge, UK

Dinwiddie, G.A., Clebsch Jr., A., 1973. Water resources of Guadalupe County, New Mexico. New Mexico State Bureau of Mines and Mineral Resources: Hydrologic Report, 3. 
El-Ashry, M.T., Vanschilfgaarde, J., Schiffman, S., 1985. Salinity pollution from irrigated agriculture. Journal of Soil and Water Conservation 40 (1), 48-52.

Fiedler, A.G., Nye, S.S., 1933. U.S. Geological Survey Water-Supply Paper, 639, p. 372.

Gibbs, R.J., 1970. Mechanisms controlling world water chemistry. Science 170 (3962), 1088-1090.

Hale, W.E., Hughes, L.S., Cox, E.R., 1954. Possible improvement of quality of water of the Pecos River by diversion of brine at Malaga Bend, Eddy County, New Mexico. Pecos River Commission, Carlsbad, New Mexico.

Harrington, E.R., 1957. Sinkholes, bottomless lakes, and the Pecos River. The Scientific Monthly 84 (6), 302-308.

Havenor, K., 2003. The geological framework of the Pecos Valley and the evolution of the Roswell groundwater basin in Chaves and northern Eddy Counties, New Mexico, AAPG Southwest Section Meeting, Ruidoso, New Mexico, June 6-8, 2002. AAPG Search and Discovery Article \#90023@2002, Ruidoso, New Mexico, pp. 170-189.

Havens, J.S., Wilkins, D.W., 1980. Experimental salinity alleviation at Malaga Bend of the Pecos River, Eddy County, New Mexico. U.S. Geological Survey WaterResources Investigations, pp. 80-84.

Hernandez, J.W., 1978. Interrelationship of ground and surface water quality in the El Paso-Juarez and Mesilla Valleys. Natural Resources Journal 18, 1-9.

Hiss, W.L., Peterson, J.B., Ramsey, T.R., 1969. Saline water in southeastern New Mexico. Chemical Geology 4 (1-2), 341-360.

Howard, C.S., White, W.F., 1938. Chemical character of Pecos River in New Mexico. Biennial Report of the State Engineer of New Mexico, Santa Fe, New Mexico.

Hoy, R., Gross, G., 1982. A baseline study of oxygen-18 and deuterium in the Roswell, New Mexico, groundwater basin. New Mexico Water Resources Research Institute Report, p. 144.

Ingvorsen, K., Zeikus, J.G., Brock, T.D., 1981. Dynamics of bacterial sulfate reduction in a eutrophic lake. Applied and Environmental Microbiology 42 (6), 1029-1036.

Johnson, K.S., 1981. Dissolution of salt on the east flank of the Permian Basin in the southwestern U.S.A. Journal of Hydrology 54 (1-3), 75-93.

Kester, C.L., Baron, J.S., Turk, J.T., 2003. Isotopic study of sulfate sources and residence times in a subalpine watershed. Environmental Geology 43 (5), 606-613.

Krouse, H.R., Grinenko, V.A., 1991. Stable isotopes: natural and anthropogenic sulfur in the environment. SCOPE, 43. John Wiley and Sons, Chichester. 440 pp.

Krouse, H.R., Mayer, B., 2000. Sulphur and oxygen isotopes in sulphate. In: Cook, P. Herczeg, A.L. (Eds.), Environmental Tracers in Subsurface Hydrology. Kluwer Acad., Boston, Mass, pp. 195-232.

Land, L., Huff, G.F., 2010. Multi-tracer investigation of groundwater residence time in a karstic aquifer: Bitter Lakes National Wildlife Refuge, New Mexico, USA. Hydrogeology Journal 18 (2), 455-472.

Lloyd, R.M., 1968. Oxygen isotope behavior in the sulfate-water system. Journal of Geophysical Research 73, 6099-6110.

Longworth, J., Carron, J, 2003. Chapter one: the physical framework - overview of water operations in the Pecos River Basin, decision-makers field guide. New Mexico Bureau of Geology and Mineral Resources, pp. 32-38.

Longworth, J.W., Valdez, J.M., Magnuson, M.L., Albury, E.S., Keller, J., 2008. New Mexico water use by categories 2005. New Mexico Office of the State Engineer, Technical Report, p. 52.

Lucas, S.G., 1991. Type section of the Permian Bernal Formation and the PermianTriassic boundary in north-central New Mexico. New Mexico Geology 13, 9-15.

Lynch, T.R., Popp, C.J., Jacobi, G.Z., Robertson, J., 1988. Assessing the sensitivity of high altitude New Mexican wilderness lakes to acidic precipitation and trace metal contamination. New Mexico Water Resources Research Institute, Las Cruces, New Mexico.

Mast, M.A., Turk, J.T., Ingersoll, G.P., Clow, D.W., Kester, C.L., 2001. Use of stable sulfur isotopes to identify sources of sulfate in Rocky Mountain snowpacks. Atmospheric Environment 35 (19), 3303-3313.

Mayer, B., Feger, K.H., Giesemann, A., Jager, H.J., 1995a. Interpretation of sulfur cycling in two catchments in the Black Forest (Germany) using stable sulfur and oxygen isotope data. Biogeochemistry 30 (1), 31-58.

Mayer, B., Fritz, P., Prietzel, J., Krouse, H.R., 1995b. The use of stable sulfur and oxygenisotope ratios for interpreting the mobility of sulfate in aerobic forest soils. Applied Geochemistry 10 (2), 161-173.

Mitchell, M.J., Krouse, H.R., Mayer, B., Stam, A.C., Z., Y., 1998. Use of stable isotopes in evaluating sulfur biogeochemitry of forest ecosystems. In: Kendall, C., McDonald, J.J. (Eds.), Catchment Hydrology. Elsevier, Amsterdam, pp. 489-518.

Nakai, N., Jensen, M.L., 1964. The kinetic isotope effect in the bacterial reduction and oxidation of sulfur. Geochimica et Cosmochimica Acta 28 (12), 1893-1912.

Plummer, L.N., Bexfield Laura, M., Anderholm Scott, K., Sanford Ward, E., Busenberg, E., 2004. Geochemical characterization of ground-water flow in the Santa Fe Group aquifer system, middle Rio Grande basin, New Mexico. U. S. Geological Survey Water-Resources Investigations Report (WRIR) 03-4131, Reston, VA.
Richter, D.D., Johnson, D.W., Todd, D.E., 1983. Atmospheric sulfur deposition, neutralization, and ion leaching in two deciduous forest ecosystems. Journal of Environmental Quality 12 (2), 263-270.

Risser, D.W., 1987. Possible changes in ground-water flow to the Pecos River caused by Santa Rosa Lake, Guadalupe County, New Mexico. U.S. Geological Survey WRIR, pp. 85-4291.

Rock, L., Mayer, B., 2009. Identifying the influence of geology, land use, and anthropogenic activities on riverine sulfate on a watershed scale by combining hydrometric chemical and isotopic approaches. Chemical Geology 262 (3-4), 121-130.

Scanlon, B.R., Stonestrom, D.A., Reedy, R.C., Leaney, F.W., Gates, J., Cresswell, R.G., 2009 Inventories and mobilization of unsaturated zone sulfate, fluoride, and chloride related to land use change in semiarid regions, southwestern United States and Australia. Water Resources Research 45 (W00A18), 1-17.

Schiff, S.L., Spoelstra, J., Semkin, R.G., Jeffries, D.S., 2005. Drought induced pulses of $\mathrm{SO}_{4}^{2}$ - from a Canadian shield wetland: use of $\delta^{34} \mathrm{~S}$ and $\delta^{18} \mathrm{O}$ in $\mathrm{SO}_{4}^{2-}$ to determine sources of sulfur. Applied Geochemistry 20 (4), 691-700.

Scofield, C.S., 1940. Salt balance in irrigated areas. Journal of Agricultural Research 61 (1), 17-39.

Shanley, J.B., Mayer, B., Mitchell, M.J., Michel, R.L., Bailey, S.W., Kendall, C., 2005. Tracing sources of streamwater sulfate during snowmelt using $\mathrm{S}$ and $\mathrm{O}$ isotope ratios of sulfate and ${ }^{35} \mathrm{~S}$ activity. Biogeochemistry 76 (1), 161-185.

Sidwell, R., 1941. Sediments of Pecos River, New Mexico. Journal of Sedimentary Petrology 11 (2), 80-84.

Solomon, D., Lehmann, J., Lobe, I., Martinez, C.E., Tveitnes, S., Du Preez, C.C., Amelung W., 2005. Sulphur speciation and biogeochemical cycling in long-term arable cropping of subtropical soils: evidence from wet-chemical reduction and SK-edge XANES spectroscopy. European Journal of Soil Science 56 (5), 621-634.

Summers, W.K., 1972. Geology and regional hydrology of the Pecos River Basin, New Mexico, Open File Report 37. New Mexico Institute of Mining and Technology, Socorro, New Mexico.

SWQB, 2003. Water quality survey summary for the upper Pecos River watershed, Part 3 (between tecolote creek and sumner reservoir) 2001. Surface Water Quality Bureau (SWOB). New Mexico Environment Department.

Taylor, B.E., Wheeler, M.C., 1993. Sulfur- and oxygen-isotope geochemistry of acid mine drainage in the western United States, Environmental Geochemistry of Sulfide Oxidation. ACS Symposium Series. American Chemical Society, pp. 481-514.

Theis, C.V., 1965. Ground water in southwestern region. In: Young, A., Galley, J.E. (Eds.), Fluids in Subsurface Environments, A Symposium. American Association of Petroleum Geologists, Tulsa, Okla, pp. 327-341.

Thomas, H.E., 1963. Causes of depletion of the Pecos River in New Mexico. U.S. Geological Survey Water-Supply Paper 1619-G, Washington, D.C.

Tuttle, M.L.W., Breit, G.N., Cozzarelli, I.M., 2009. Processes affecting $\delta^{34} S$ and $\delta^{18} O$ values of dissolved sulfate in alluvium along the Canadian River, central Oklahoma, USA. Chemical Geology 1-13. doi:10.1016/j.chemgeo.2009.05.009.

Uliana, M.M., Banner, J.L., Sharp, J.M., 2007. Regional groundwater flow paths in TransPecos, Texas inferred from oxygen, hydrogen, and strontium isotopes. Journal of Hydrology 334 (3-4), 334-346.

USGS, 2010. National Water Information System: Web Interface - USGS 08407500 Pecos River at Red Bluff, NM. U.S. Geological Survey (USGS). http://waterdata. usgs.gov/nwis/nwisman/?site_no $=084075002010$ accessed on February 18, 2011.

Van Denburgh, A.S., Feth, J.H., 1965. Solute erosion and chloride balance in selected river basins of the western conterminous United States. Water Resources Research 1 (4), 537-541.

Van Stempvoort, D.R., Krouse, H.R., 1994. Controls of $\delta^{18} \mathrm{O}$ in sulfate: a review of experimental data and application to specific environments. In: Alpers, C.N., Blowes, D.W. (Eds.), Environmental Geochemistry of Sulfide Oxidation. ACS Symposium Series. American Chemical Society, pp. 446-480.

Wilson, B.C., Lucero, A.A., Romero, J.T., Romero, P.J., 2003. Water use by categories in New Mexico counties and river basins, and irrigated acreage in 2000. New Mexico Office of the State Engineer: Technical Report, 51.

Yuan, F., Miyamoto, S., 2004. Influence of the Pacific Decadal Oscillation on hydrochemistry of the Rio Grande, USA, and Mexico. Geochemistry, Geophysics, Geosystems 5 (12), 1-10.

Yuan, F., Miyamoto, S., 2005. Dominant processes controlling water chemistry of the Pecos River in American southwest. Geophysical Research Letters 32 (17), 1-4.

Yuan, F., Miyamoto, S., 2008. Characteristics of oxygen-18 and deuterium composition in waters of the Pecos River in American Southwest. Chemical Geology 255 (1-2), 220-230.

Yuan, F., Miyamoto, S., Anand, S., 2007. Changes in major element hydrochemistry of the Pecos River in the American Southwest since 1935. Applied Geochemistry 22 (8), 1798-1813. 